\title{
Retraction Note: Correlation of CD44v6 expression with ovarian cancer progression and recurrence
}

\author{
Jun Shi ${ }^{1,2}$, Zhou Zhou', Wen $\mathrm{Di}^{2 \dagger}$ and Ningli $\mathrm{Li}^{{ }^{*+}}$
}

\author{
Retraction Note: BMC Cancer (2013) 13: 182 \\ https://doi.org/10.1186/1471-2407-13-182
}

The authors have retracted this original article [1] because a number of the figures exhibit irregularities.

Specifically:

- Figure $1 \mathrm{C}$ appears to be comprised of lanes from multiple gels, with only one loading control. Further, the CD44v6 lanes seem to be rotated 180 degrees.

- In Figure 3, panels $\mathrm{C}$ and $\mathrm{F}$ overlap extensively.

- In Figure 5B, panels A and B overlap extensively.

- In Figure 5C, panels $C$ and D overlap extensively. Also, panel $\mathrm{D}$ appears to be rotated 90 degrees.

As these irregularities undermine the conclusions presented, the Editor no longer has confidence in the article.

All authors agree with this retraction.

\section{Author details}

'Shanghai Institute of Immunology, Shanghai Jiao Tong University School of Medicine, Shanghai 200025, People's Republic of China. ${ }^{2}$ Department of Obstetrics and Gynecology, Ren ji Hospital, School of Medicine, Shanghai Jiao Tong University, Shanghai 200127, People's Republic of China.
Published online: 19 March 2020

Reference

1. Shi J, Zhou Z, Di W, et al. Correlation of CD44v6 expression with ovarian cancer progression and recurrence. BMC Cancer. 2013;13:182. https://doi. org/10.1186/1471-2407-13-182.

The original article can be found online at https://doi.org/10.1186/1471-240713-182.

* Correspondence: ninglixiaoxue57@yahoo.com.cn

${ }^{+}$Wen Di and Ningli Li contributed equally to this work.

'Shanghai Institute of Immunology, Shanghai Jiao Tong University School of Medicine, Shanghai 200025, People's Republic of China

Full list of author information is available at the end of the article

(c) The Author(s). 2020 Open Access This article is licensed under a Creative Commons Attribution 4.0 International License, which permits use, sharing, adaptation, distribution and reproduction in any medium or format, as long as you give appropriate credit to the original author(s) and the source, provide a link to the Creative Commons licence, and indicate if changes were made. The images or other third party material in this article are included in the article's Creative Commons licence, unless indicated otherwise in a credit line to the material. If material is not included in the article's Creative Commons licence and your intended use is not permitted by statutory regulation or exceeds the permitted use, you will need to obtain permission directly from the copyright holder. To view a copy of this licence, visit http://creativecommons.org/licenses/by/4.0/. The Creative Commons Public Domain Dedication waiver (http://creativecommons.org/publicdomain/zero/1.0/) applies to the data made available in this article, unless otherwise stated in a credit line to the data. 